\title{
UDDER HEALTH AND MILKING TECHNOLOGY ON THE HUNGARIAN LARGE-SCALE DAIRY FARMS
}

\author{
D. Ivanyos ${ }^{1 *}$, A. Monostori ${ }^{2}$, Cs. Németh ${ }^{2}$, I. Fodor $^{1}$, L. Ózsvári $^{1}$ \\ 1 University of Veterinary Medicine Budapest, Hungary \\ 2 Livestock Performance Testing Ltd., Gödöllö, Hungary \\ https://doi.org/10.47833/2020.2.AGR.021
}

\author{
Keywords: \\ dairy \\ milking technology \\ udder health \\ milk production \\ milk quality
}

\section{Article history:}

\begin{abstract}
The aim of this study was to survey the milk yield, milk quality and milking technology on Hungarian large-scale (>50 cows) dairy farms and to evaluate the possible impact of milking parlour type on milk production and quality (somatic cell count). The survey was performed by using a questionnaire on 377 Hungarian dairy farms in 2017. Farms were categorized according to their milking parlour types (herringbone, parallel, carousel and others). The average SCC on the Hungarian dairy farms was high $(405,199 \mathrm{SCC} / \mathrm{ml})$. Farms using herringbone milking system had the lowest milk quality (429.240 SCC/ml) and milk yield (27.01 kg/day). The type of milking parlour had an impact on milk quality $(p=0.05)$ and milk yield $(p=0.03)$.
\end{abstract}

\section{Introduction}

On dairy farms like in any enterprise the ultimate goal is increasing the profit. Profitability can be achieved by increasing the amount of marketable products and the quality paid by the market or decreasing the production costs [1].

Major losses associated with mastitis have been studied in the past and identified as reduced milk production, milk composition changes, discarded milk, veterinary fees, drug costs, farmers' extra labour, premature disposal and preventive measurements' costs. A reduction in milk yield has the greatest impact from an economic point of view, therefore the subclinical mastitis is of larger importance than the clinical form, albeit the costs due to discarded milk, medication, veterinary fees and the farmers' extra labour could also be significant [2]-[5].

2015-2016 has brought the third crisis of the global dairy market since 2007. In February 2014, the global milk price reached its highest level (56 \$/100 kg ECM), which fell to an average of $34 \$ 100 \mathrm{~kg}$ ECM to $22.1 \$ 100 \mathrm{~kg}$ ECM by May 2016. At the same time, the abolition of the milk quota system in the European Union made the competition between dairy farmers even more sharp, which makes profit-oriented farming even more important.

There are several reasons for the growing awareness of udder health issues on dairy farms. Firstly, in Europe, the EEC directive 92/46 in April 1992 stated that milk with a somatic cell count (SCC) over 400,000 cells per ml may not be used for fluid milk and starting in 1998 not even fit for human consumption. Secondly, the awareness related to animal welfare issues increased, as well. A third, more recent issue is human health concerns regarding antibiotic residues in milk, transfer of antibiotic resistance from animal to human, and that of pathogens through milk or milk products [6].

The most significant subclinical abnormality of the milk is the increase in the somatic cell counts (SCC), which is the most common measurement of milk quality and udder health

\footnotetext{
*Corresponding author. Tel.: +36-1-478-4185

E-mail address: ivanyos.dorottya@univet.hu
} 
[1], [7]. An elevated SCC is a practicable approach in order to detect subclinical forms of mastitis. A SCC below $100,000 \mathrm{cells} / \mathrm{ml}$ is currently set as the physiological limit [8]. The main factor that affects the somatic cell count (SCC) is the presence of infection in the mammary gland (mastitis) that occurs by the invasion of microorganisms, which results in the increase of the animal defence cells (somatic cells) in the milk [9].

Technological diversity has an impact on milk production, particularly on milk quality. Dairy farms in Hungary have different type of milking technologies depending on herd size, housing, available labour and investment capital. Categorized by the way of housing, in tied housing systems bucket machine, tank truck and pipeline milking machine can be used, while in loose housing systems we can distinguish stable flooring (tandem, herringbone, parallel, polygon), moving flooring (carousel, head carriage) milking systems and milking robots [10]. It is economically efficient on farms with less than 30 cows to use bucket machine milking. If the size of a herd varies between 30-50 cows, it is more efficient to use milking systems with a milk pipeline in the cowshed and non-automated equipment. Larger dairy herds require a milk pipeline and automated equipment or a milking parlour [11]. The most common milking system on large-scale dairy farms is herringbone, but parallel, tandem and carousel milking technology is also used, but in recent years the spread of robot milking systems also started [12]. The modernisation of milk production is directly associated with an increase in herd size, which allows the farm to efficiently exploit the newest technologies and rationally use its labour [11].

\section{Method}

Our survey was conducted by using a questionnaire on 377 large-scale ( $>50$ cows) Hungarian dairy farms in 2017, and it was compared with the official farm milk production data. On the surveyed farms milk performance test is conducted monthly that is based on individual milk samples from all milking cows. For the categorization by parlour types four groups were set up: herringbone, parallel, carousel and others. Data were processed in MS Excel 2013 software (Microsoft Corporation, Redmond, WA, USA). The relationships were analysed by two-way ANOVA. Pairwise comparisons were performed by Tukey's post hoc tests. Statistical analyses were performed in $\mathrm{R}$ version 3.5.1. (R Core Team, 2018).

\section{Results}

The survey was conducted on 377 dairy farms with 176,400 cows in Hungary. The average cow number on the surveyed farms was $467,90 \pm 367,02$ cows, the average daily milk yield was $28.40 \pm 5.87 \mathrm{~kg} /$ day and the average SCC was 405,199 $\pm 176,634 \mathrm{cell} / \mathrm{s} / \mathrm{ml}$. The most common used milking parlour type was herringbone (257 farms, $68.2 \%)$, that was followed by parallel (62 farms, 16.4\%), carousel (40 farms, 10.6\%) and other type like pipeline, tandem and robot (18 farms, $4.8 \%$ ).

As the average cow number increased so did the occurrence of parallel and carousel parlour $(p<0.001)$. The type of parlour had an impact on the daily milk yield $(p=0.027)$ and we found significant differences between parallel and herringbone parlour $(p=0.014)$. Farms using herringbone parlour produced the lowest amount of milk on average (Table). 
Table. Average cow number, daily milk yield and SCC according to the type of milking parlour $(n=377)$

\begin{tabular}{lccc}
\hline & $\begin{array}{c}\text { Average cow } \\
\text { number }\end{array}$ & $\begin{array}{c}\text { Daily milk yield } \\
(\mathrm{kg} / \text { day })\end{array}$ & $\begin{array}{c}\text { SCC } \\
\left(\times 10^{3} \mathrm{cell} / \mathrm{ml}\right)\end{array}$ \\
\hline Herringbone & $343 \pm 237$ & $27.01^{\mathrm{a}} \pm 5.72$ & $429.24^{\mathrm{a}} \pm 181.89$ \\
Parallel & $656 \pm 281$ & $31.76^{\mathrm{b}} \pm 5.18$ & $349.80^{\mathrm{a}} \pm 154.13$ \\
Carousel & $900 \pm 351$ & $31.35^{\mathrm{ab}} \pm 5.10$ & $324.26^{\mathrm{a}} \pm 150.48$ \\
Other & $616 \pm 367$ & $29.28^{\mathrm{ab}} \pm 5.90$ & $378.00^{\mathrm{a}} \pm 176.54$
\end{tabular}

a, b Groups with different superscripts differ significantly $(p<0.05)$.

SCC did not show significant differences regarding to the type of milking parlour, however farms using herringbone parlour showed the lowest milk quality.

\section{Discussion}

Nipers et al. [11] recommended a separate parlour over 200 cows. Hungarian farms with smaller number of cows have already used separate milking parlours and like in Latvia the herringbone parlour is the most common used type of milking parlour, although farms with herringbone parlour produced the poorest quantity and quality milk.

The average SCC on the Hungarian dairy farms is high regardless the type of milking parlour, which has a detrimental impact on the milk production, as well [3]. Regarding our results as well groups with lower SCC produced more milk on average. Pfützner et al. [13] found even cows with a SCC below 100,000 cells $/ \mathrm{ml}$ showed a remarkable production loss of over $8 \%$. In order to meet the growing food hygiene demands of the European Union's market Hungarian dairy farmers are under increasing pressure.

The lower milk production in smaller dairy farms, where herringbone parlours were mostly used can be explained with lower standards of housing, feeding, milking technology and genetics [14]. Higher cow number and milk production enable the use of newer technologies, which could have an impact on production [11]. In the current economic circumstances, in order to produce profits for Hungarian dairy farmers, they need to close the gap in animal health management. Accordingly, dairy farmers aim to increase their income with production-oriented health management - which, in addition to classical veterinary activities, also takes into account management and production factors and implements an integrated approach - contributes greatly to the beneficial and competitive production of high quality raw milk. Further research is required regarding udder health management and farm practices in Hungarian dairy farms to find the source of the problem of the average low milk quality in Hungary.

\section{Conclusion}

Udder health has many other aspects that can influence the milk quantity and quality. We can conclude that milking parlour type is one of the influencing factor. With larger milk production farms allow the use of newer technologies what can help to improve the milk quality, but smaller farms can produce with proper hygiene and routine good quality milk as well.

\section{Acknowledgement}

The Project was supported by the European Union and co-financed by the European Social Fund: (1) EFOP-3.6.1-16-2016-00024 'Innovations for Intelligent Specialisation on the University of Veterinary Science and the Faculty of Agricultural and Food Sciences of the Széchenyi István University Cooperation'; (2) EFOP-3.6.2-16-2017-00012 ‘Development of a 
product chain model for functional, healthy and safe foods from farm to fork based on a thematic research network'; and (3) EFOP-3.6.3-VEKOP-16-2017-00005 'Strengthening the scientific replacement by supporting the academic workshops and programs of students, developing a mentoring process'.

\section{References}

[1] L. Ózsvári, (2004): Economic analysis of decisions with respect to dairy cow health management. PhD dissertation. Szent István University, Faculty of Economics and Social Sciences, Institute of Economic Analysis and Methodology, Gödöllö. p. 145.

[2] K. Huijps, H. Hogeveen, T. J. G. M. Lam, R. B. M. Huirne, (2009): Preferences of cost factors for mastitis management among Dutch dairy farmers using adaptive conjoint analysis. Prev. Vet. Med., vol. 92, no. 4, pp. 351-359

[3] L. Ózsvári, I. B. Csaba, A. Fux, O. Bíró, (2003): The quantification of the economical losses caused by Staphylococcus aureus in a large-scale Holstein-Friesian dairy cattle farm. (in Hungarian with English abstract). Magyar Allatorvosok Lapja, vol. 125, no. 5, pp. 273-279.

[4] H. Seegers, C. Fourichon, F. Beaudeau, H. Seegers, C. Fourichon, F. Beaudeau, (2003): Production effects related to mastitis and mastitis economics in dairy cattle herds. Vet. Res., vol. 34, pp. 475-491.

[5] C. Yalcin, A. W. Stott, D. N. Logue, J. Gunn, (1999): The economic impact of mastitis-control procedures used in Scottish dairy herds with high bulk-tank somatic-cell counts. Prev. Vet. Med., vol. 41, no. 2-3, pp. 135-149.

[6] R. N. G. Ynte H. Schukken*, D. J. Wilson, F. Welcome, L. Garrison-Tikovsky, (2003): Monitoring udder health and milk quality using somatic cell counts. Vet. Res., vol. 35, no. Vet. Res. Volume 34, Number 5, September-October 2003 Mastitis of dairy ruminants, pp. 579-596.

[7] P. L. Ruegg, (2017): A 100-Year Review: Mastitis detection, management, and prevention. J. Dairy Sci., vol. 100, no. 12, pp. 10381-10397.

[8] D. Schwarz, U. S. Diesterbeck, S. König, K. Brügemann, K. Schlez, M. Zschöck, (2011): Flow cytometric differential cell counts in milk for the evaluation of inflammatory reactions in clinically healthy and subclinically infected bovine mammary glands. J. Dairy Sci., vol. 94, no. 10, pp. 5033-5044.

[9] J. R. R. de Roza, Lenilson da Fonseca, Lopes, Leandro Sâmia, Simioni, Flávio José, Silva, Aleksandro Schafer da, Schonell, Evandro Paulo, Carvalho, (2015): Milk quality of properties with different technological standards. Biosci. J., vol. 31, no. 6, pp. 1760-1770.

[10] B. Béri, (2011): Milking, feeding and drinking technology in cattle breeding (in Hungarian). in Tartástechnológia, B. Béri, Ed. 2011, pp. 20-27.

[11] A. Nipers, I. Pilvere, A. Valdovska, L. Proskina, (2016): Assessment of key aspects of technologies and cow farming for milk production in Latvia. in Engineering for Rural Development, vol. 15, pp. 175-181.

[12] J. Priekulis, A. Kurgs (2010): Economically most efficient equipment in milking parlours. in Engineering for Rural Development, pp. 93-96.

[13] M. Pfützner, L. Ózsvári, (2017): The Financial Impact of Decreased Milk Production Due to Subclinical Mastitis in German Dairy Herds. J. Fac. Vet. Med. Istanbul Univ., vol. 2, no. 43, pp. 110-115.

[14] A. C. O. Rodrigues, D. Z. Caraviello, P. L. Ruegg, (2005): Management of Wisconsin Dairy Herds Enrolled in Milk Quality Teams. J. Dairy Sci., vol. 88, no. 7, pp. 2660-2671. 